\title{
生活環境リスクに関する実態調 COMPREHENSIVE RESEARCHES ON ACTUAL RISKS CONCERNING LIVING ENVIRONMENT
}

\author{
青木 仁 — $* 1 \quad$ 中山和美 $-* 2$ \\ キーワード : \\ 防災，防犯，都市生活，アンケート調査 \\ Keywords: \\ Disaster prevention, Crime prevention, Urban lifestyle, Questionnaire
}

Hitoshi AOKI $-* 1 \quad$ Kazumi NAKAYAMA $-* 2$

National wide researches were carried out in order to obtain actual risks concerning living environment. The results of the inquiry are shown as follows.

1) A large number of respondents worry something unsatisfactory coming up against crimes or disasters.

2) Remarkable risks are different from respondents' situation, such as living area, age, and house.

3) Several numbers of measures are taken to deal with some risks.

4) Many people expect informational exchange multilaterally.
1.はじめに

私達は, 安心で安全な生活を望んでいるが, 近年, 災害や犯罪な ど,生活環境リスクについて論じられる機会が多くなっている。

生活環境上のリスクや, リスクといえないまでも居住者が不安に 感じる問題に対し, 従来は, 震災に起因するリスク, 火災に起因す るリスク, 日常災害に起因するリスク等, カテゴリーに分類し，そ れぞれ縦割りの対策が検討され，講じられてきた。しかし，これら の対策に関し, 実際にどのように防災, 防犯策を講じるかは生活者 の裁量に任されている。生活環境のリスク・不安の全体像を把握し た上で, その緊急性あるいは効果による優先順位を付け, 対策を取 捨選択しやすいように生活者に情報を提供する必要がある。

防災や避難に関する既往の研究は多くなされているが，都市にお ける密集市街地のリスクに着目すると, 齍藤ら 3による火炎延焼リ スクの簡易的評価手法の研究, 今泉ら 4)による震災時の道路閉塞推 定に関する研究等が挙げられる。これらは都市構造や道路巾員が主 題であり, 生活環境リスクを総合的に, 生活者の視点で検討した研 究はほとんどない。

一方, 生活環境のリスク・不安には, 建築や都市の構造上の問題 だけでなく，ライフスステージなど住まい手に起因する場合や，家 具の配置など住まい方に起因する場合もある。しかし，こうしたリ スクは顕在化する機会が少なく，十分に対策がとられているとはい えない。居住者の避難に関する既往の研究としては, 古川らうによ る高齢者の避難行動特性を把握した研究などがあるが, 建物内の避 難時の行動のみを対象としている。

都市生活者のリスクを総合的に検討するためには，まず，居住者 がどのようなリスクを認識し，対策を施しているかについて，居住 地域, 住宅の状態, 居住者を連続的に, かつ都市以外の居住者の実
態と対比させて把握する必要がある。そこで, 生活環境リスクに関 する全国規模のアンケート調查を実施し, 日常起こりうる災害や不 安に関する不備感, 実際に実施されている対策, 情報交換の意識と 実態について明らかにした結果を報告する。

\section{2. 調查概要}

全国 2000 世帯を対象に, 層下多段無作為抽出法で 200 地点を選 択し, 質問紙を用いた戸別訪問調查（期間 : 2005 年 3 月 3 日〜 3 月 14 日）を実施した。質問は, 回答者のプロフィールと, 生活環境に 関連する犯罪・災害に対する回答者の意識と実態に関する項目であ る (表 1 )。設問は, 日常起こりうる災害として地震や水害などの天 災, 交通事故や火災などの人災, 穷盗など, 生活環境で改善できる ものを対象とした。設問は, 複数の選択肢からあてはまるものすべ てを選択させる方法とした。なお, 調查実施直前の 2004 年 (平成 16 年）は， 6 月から 10 月にかけて複数の台風による大雨の被害, 2004 年 10 月 23 日には中越地震, 12 月 26 日にはスマトラ沖地震 津波が発生するなど, 1 年の間に自然災害が多数起こり, 日本中が 災害を身近に感じた年であったといえる。

\section{表 1 質問項目}

\begin{tabular}{|l|l|}
\hline $\begin{array}{l}\text { 回答者 } \\
\text { 属性 }\end{array}$ & $\begin{array}{l}\text { 地域, 都市規模 } \\
\text { 性別, 年㱓, 家族構成, 住宅・居住歴 }\end{array}$ \\
\hline 設問 & $\begin{array}{l}\text { 災害に対し, 住宅・地域にある不備 (24 選択肢) 表 } 2 \text { 参照 } \\
\text { 災害対策で, 具体的に実行しているか検討しているもの (18 選 } \\
\text { 択肢) 表 } 3 \text { 参照 } \\
\text { 情報交換の方法について (6 選択肢) 表 } 4 \text { 参照 }\end{array}$ \\
\hline
\end{tabular}

\section{3. 結果 · 考察}

\section{1 調査世帯のプロフィール}

回答者は, 1,252 人（男性 587 人，女性 665 人）, 回収率は $56.9 \%$

\footnotetext{
*1 R\&D Center, Tokyo Electric Power Company, M. Eng.

*2 R\&D Center, Tokyo Electric Power Company, Dr. Eng.
} 
$\begin{array}{lllll}0 & 10 & 20 & 30 & 40\end{array}$

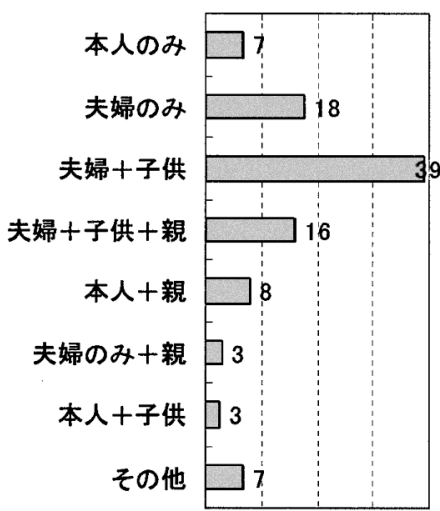

(1) 家族構成

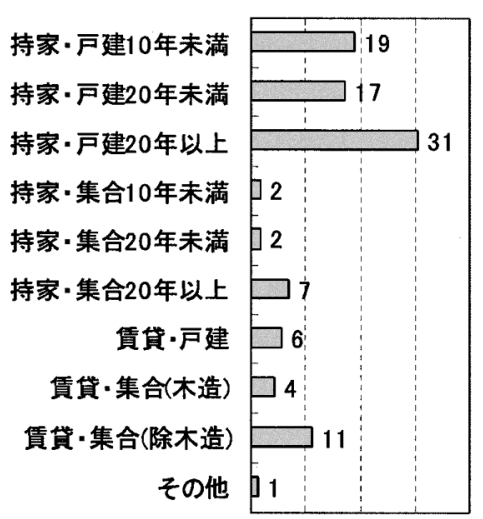

(2)住宅タイプ

図 1 属性分布

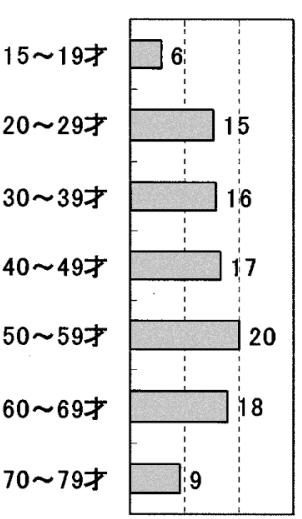

（3）年齢構成

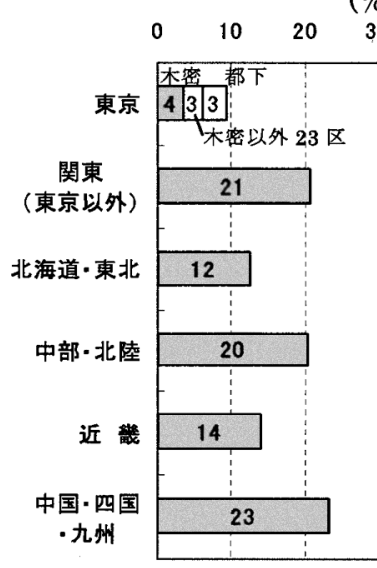

（4）居住地域
であった。回答結果は，全体的な傾向と，調査対象者を図 1 に示す 4 属性に着目して考察を行った。

(1) 家族構成: [夫婦十子供] 世帯が最も多く全体の約 4 割, 次 に[夫婦のみ], [夫婦十子供十親 ] であった。

(2) 住居タイプ: 20 年以上の持家・戸建が最も多く, 全体の約 3 割であった。持家率は, 約 $78 \%$ であった。

(3) 回答者年齢：15 79 歳で, 回答率に大きな偏りはみられな かった。

(4) 居住地域: 北海道 - 東北, 関東, 中部 - 北陸, 近畿, 中国 四国・九州の 5 エリアで, $10 \%$ 以上ずつの回答を得た。また， 特に都市の生活環境整備の比較という観点から, 東京都につ いては，木造住宅密集地域（東京 23 区内で，東京都都市整 備局が定めた地域の回答者 39 名), 東京 23 区内で木造住宅 密集地域以外 (回答者 33 名) の分類項目を設定した。また, 東京居住者との比較対象として, 中部圈（愛知県の回答者 80 名), 大阪圈 (大阪府, 京都府, 兵庫県の回答者 376 名) に ついても，属性の影響を分析対象とした。

属性間の関係で特徴が見られたのは，以下の通りである。

- 回答者が 50 歳以上の世帯の $40 \%$ 以上は, 築 20 年以上の戸建 持家住宅に住んでいる。

- 60 歳代の $32 \%, 70$ 歳代の $23 \%$ の回答者は, 夫婦のみで生活. している。

・賃貸集合住宅に居住する回答者の $40 \%$ は, 本人のみの単身者 である。

- 夫婦十親の $51 \%$, 夫婦十子供十親の $48 \%$ の回答者は, 築 20 年以上の持家戸建住宅に住んでいる。

・ 木造密集地域の回答者は, $23 \%$ 賃貸集合住宅に, また 20 歳 代が $26 \%$ 住んでいる。

\section{2 災害・犯罪に対する不備の実態}

「起こりうる災害に対して, 現在のお住まいやその地域には, ど のような不備があると思いますか。あてはまるものをすべて選んで ください。という問いについて, 全体的な傾向について, 選択肢ご との選択率（選択者数 $\div$ 全回答者数 $\times 100$ ）を表 2 に示す。
表 2 災害・犯罪に対する不備選択率

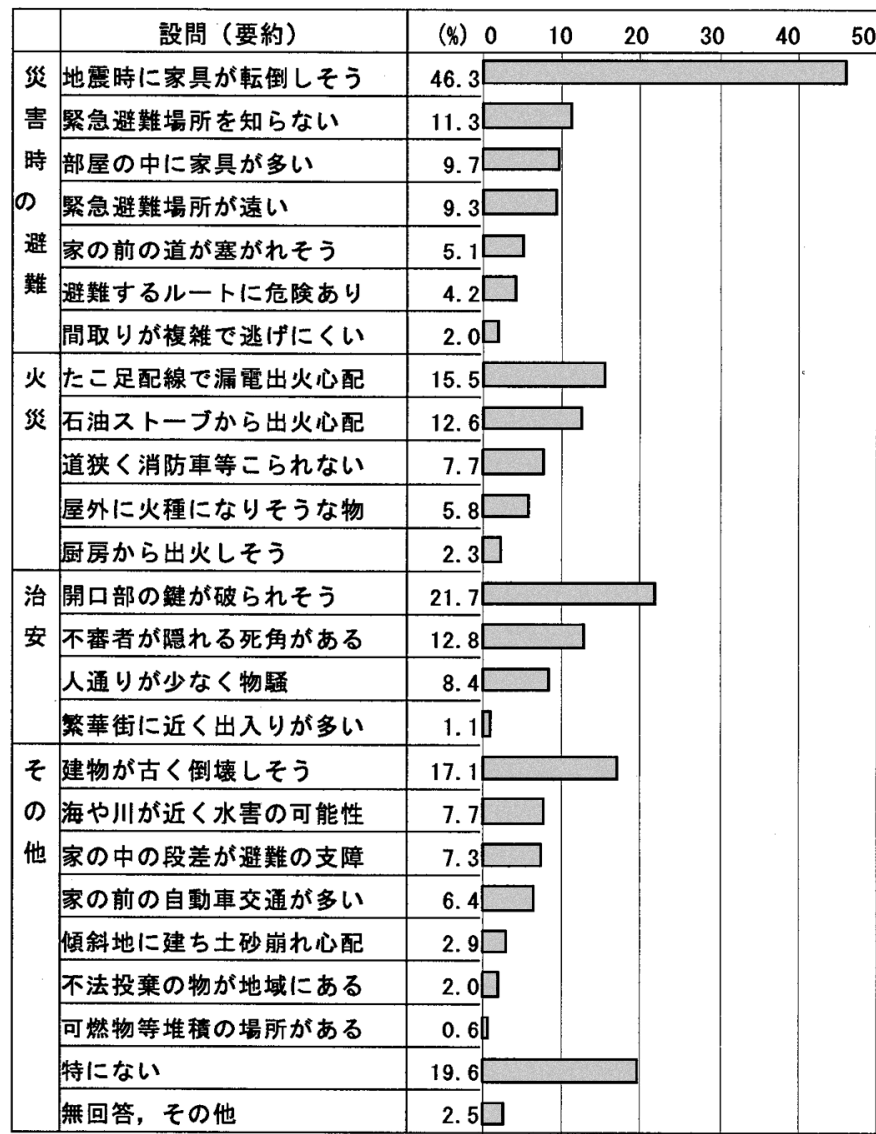

地震時に家具の転倒の不備が最も多く, 次に開口部の鍵が破られ そうだ等, 住宅内の不備について選択率が高い。

次に, 属性ごとに, 回答の特徵を抽出する。ここでは, 全体平均 と各属性の平均を比較し， $5 \%$ 以上差の生じた項目に着目した。

最も平均回答率の高かった地震時の家具の転倒については, 住宅 タイプ, 家族構成, 回答者年齢, 居住地域のいずれの属性にも回答 の偏りはみられなかった。

家族構成別に特徴をみると, 本人のみの回答者（単身者）は, 建 物が古くて崩壊しそう $(27 \%)$, 避難場所を知らない（24\%）とい 
った項目で平均より $10 \%$ 高い回答率であった。本人十親世帯の回答 者は, 建物崩壊 $(24 \%)$ ，ストーブ出火 $(20 \%)$ で平均回答率より 高い値を示した。本人十子供世帯の回答者は, 開口部の鍵が破られ そうだ $(36 \%)$ ，たこ足配線で漏電出火心配 $(36 \%)$ ，人通りが少な く物騒 $(24 \%)$, 避難場所を知らない $(18 \%)$ など, 多くの項目で 平均回答率より高い值を示した。

住宅タイプで特徴をみると, 特にないという回答が, 戸建賃貸の 居住者で $11 \%$ と少なく，なんらかのリスクを感じていることがわか る。建物の崩壊のリスクについては，住宅タイプによる差が見られ た（図 2)。持家の住宅では，古いほど倒壊のリスクを感じている。

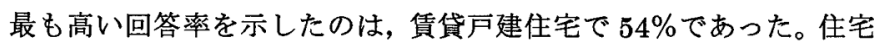
需要実態調查 6 )によると, 賃貸戸建住宅に対する不満率は高く, リ スクに対しても同様の結果が表れたといえる。

また, 筑 10 年末満の持ち家集合住宅と賃貸木造集合住宅で, 多 くの項目で平均値を上回った。平均との差が $10 \%$ を超える項目につ いて, 図 3 に示す。筑 10 年末満の持ち家集合住宅は, 建物の倒壊 については平均を大きく下回る $(4 \%)$ ものの，開口部がやぶられ そう $(30 \%) ，$ たこ足配線 $(35 \%)$ ，屋外に火種がある（13\%）とい った住宅内のリスクだけでなく，死角がある（22\%），避難場所を 知らない $(26 \%)$ ，人通りが少なく物騒（26\%）など，地域に関す るリスクについても平均より高い值を示した。築 10 年末満の持ち 家集合住宅の居住者は, 建物が新しく, 倒壊の危機感が少ない分, 他の項目に注意が注がれるのではないか。一方，賃貸木造集合住宅 は，開口部がやぶられそう（35\%），建物崩壊（33\%），たこ足配線 $(24 \%)$, 避難場所を知らない $(20 \%)$ で平均よりも高い回答率で あった。

年齢構成で特徴をみると，特に 20 代で，たこ足配線（24\%）， ス トーブ出火 $(19 \%)$, 避難場所を知らない $(21 \%)$ で，リスク意識 が高く，70 代になると，特にない $(30 \%)$ が多くなる。

居住地域で特徴をみると, 地域による特徴はあまり見られなかっ たが，木造密集地域で，死角がある $(21 \%)$ ，避難場所を知らない $(23 \%)$, 緊急避難場所が遠い $(23 \%)$, 避難ルートが危険 (18\%) など, 多くの項目で平均よりも不備であると感じられていた。

\section{3 災害・犯罪に対する対策の現状}

「日常生活で起こりうる災害で，災害に対する具体的な対策のう ち現在実行しているか，現在具体的に検討していることはあります か。あてはまるものをすべて選んでください。」という設問の回答に ついて, 全体的な傾向について選択肢ごとの選択率を表 3 に示す。 煙草の火の始末やガスの元栓など，火災に対する対策は $20 \%$ 以上が 対策をとっているが，特にないの回答も $20 \%$ 以上であった。

家族構成別に特徽をみると，本人のみの世帯は，40\%が「特にな いと回答している。夫婦のみの世帯は，25\%が放火防止に可燃物 を置かないと回答している。本人十親世帯では, 背の高い家具を固 かない $(7 \%)$, 近隣とコミュニケーションをとる ( $8 \%)$, 独力で不 審者侵入防止策を講じる $(8 \%)$, 緊急連絡先を揭示する $(8 \%)$ と, 全体的に平均を下回る回答であった。

住宅タイプ別に特徵をみると, 背の高い家具を置かない項目で, 住宅タイプによる違いが顥著であり（図 4), 新しい持家では対策を 取っている一方, 賃貸・集合 (木造) や築 20 年以上の持家・集合

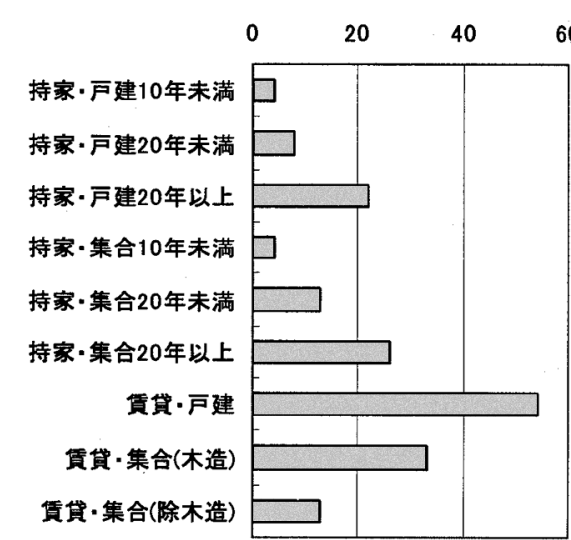

図 2 「建物が古くて崩壊しそう」回答と住宅タイプの関係

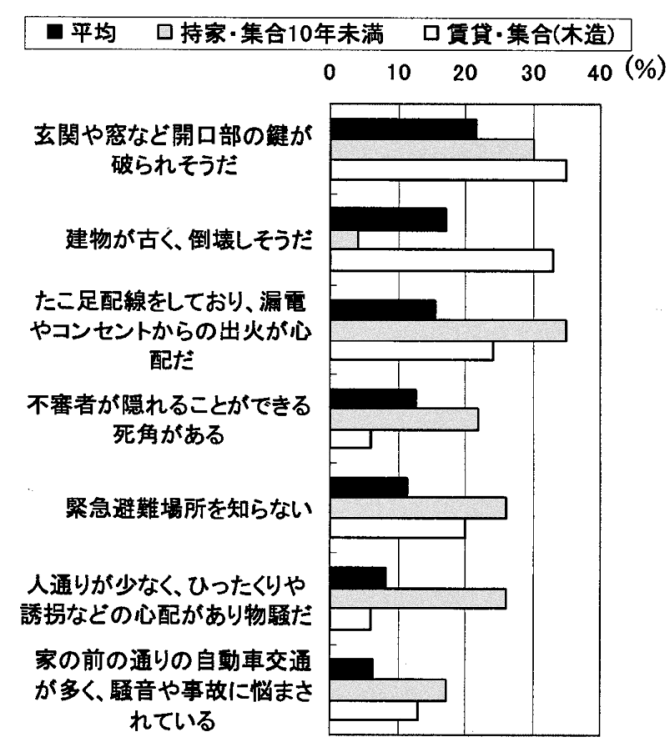

図3 築 10 年未満の持ち家集合住宅と䨘貸木造集合住宅で 平均との差が大きかった回答項目

表 3 実施中具体的対策選択率

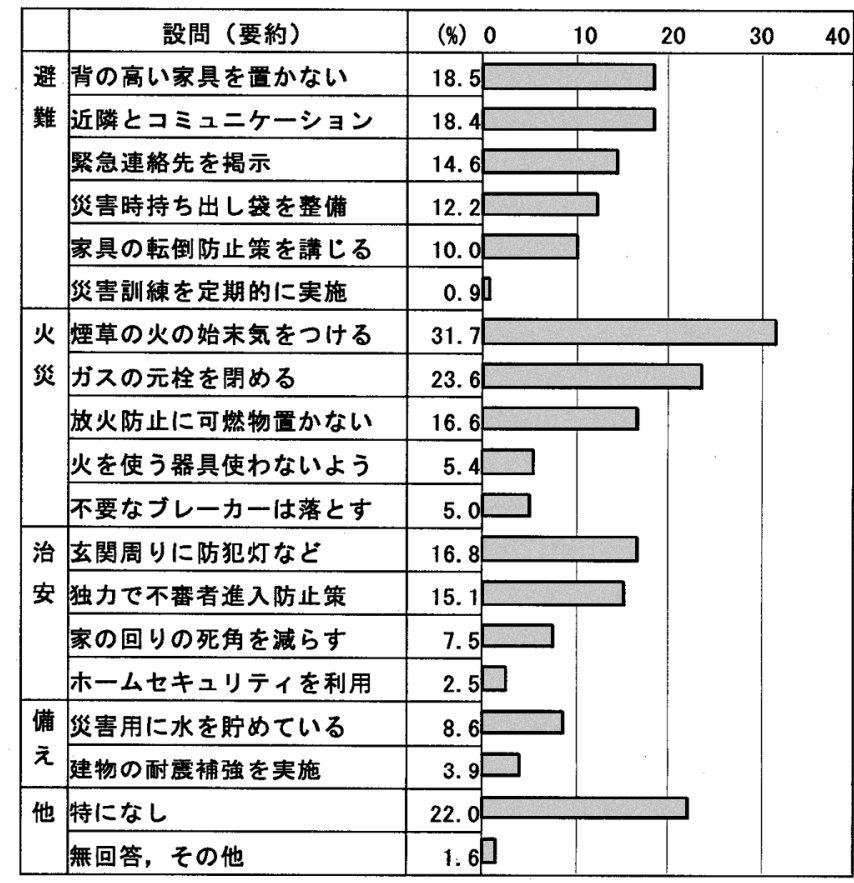


住宅では対策がとられていない。

年齢構成で特徴をみると， 20 代以下は $35 \%$ 以上が特にないと回 答している。一方， 70 代で，独力で不審者侵入防止 $(22 \%)$, 緊急 連絡先を揭示 $(28 \%)$, 非常時持ち出し袋の整備 $(19 \%)$ と, 多く の対策で，平均以上の回答を示した。

居住地域で特徵をみると, 中部圈で, 背の高い家具を割ける $(26 \%)$ ，放火防止に可然物を避ける $(33 \%)$, 独力で不審者侵入防 止策を講じる $(24 \%)$, 非常時持ち出し袋の整備 $(29 \%)$, 家具の転 倒防止 $(20 \%)$ ，災害用に水を貯める $(19 \%)$ と，多くの対策で， 平均以上の回答を示した。

\section{4 災害に対する情報コミュニケーション}

「日常起こりうる災害に対して, 地域, 家, 職場, 学校などで, どのように情報交換していくべきだと思いますか。既に実施してい るもの，寒施すべきだと考えるものをすべて選んでください。」とい う設問について，全体的な回答の傾向について，選択肢ごとの選択 率を図 5 に示す。既に家族で相談しているか，家族で相談すべきだ と考えている人が全体の約 $1 / 3$, 近隣との情報交換, 学校で指導, 行政機関の情報把握, 地域の避難訓練は, 現状は 10～20\%行われて いるが，実施す心゙きだと考えている人が多い。選択肢間のクロス集 計を行ったところ，特に何もしていないが家族と相談すべきである

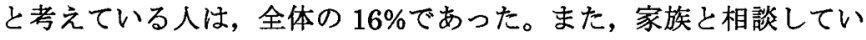

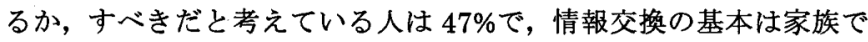
あるといえる。一方，現在何もしておらず，何をすべきでもないと

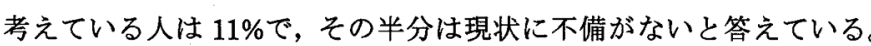

既に実施されている項目について，家族構成別に特徵をみると， 本人のみの世帯は，既に実施している項目が特になしが $60 \%$ ，実施

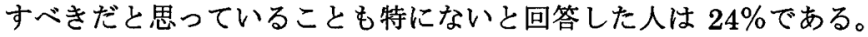
子供のいる世帯では, 学校指導が既に実施されている項目であった。 住宅所有形態で特徵をみると築 10 年以上 20 年未満の持家集合住宅 の回答者は，学校指導 $(38 \%)$, 近所と情報交換 $(21 \%)$, 地域で避 難訓練（21\%）を既に塞施していると回答している。年齢構成で特 徽をみると，学校で指導を既に寒施しているのが 10 代 (54\%)，30 代 $(26 \%) ， 40$ 代 (31\%) と多く，10 代は本人の，30 代，40 代は 子供の学校の指導によると考えられる。居住地域で特徴をみると, 中部圈では学校指導 $(26 \%)$, 大阪圈では近隣情報 $(21 \%)$ が，平 均を上回った回答率であった。

一方，実施すべきだと考えている項目に関する属性の違いは多く なかったが, 23 区居住者の $64 \%$ が家族と相談すべきだと回答した。

\section{4. まとめ}

住環境の防災・防犯に関し，居住者の不備意識と実際の対策につ いて全国調查を行った。その結果，災害や犯罪に対して，多くの人 が不備を感じていること，また，不備を感じていながらも，十分な 対策がとられていない実態が明らかになった。さらに, 住宅タイプ, 居住地域, 年齢など回答者の属性と, 不備意識, 対策の実態との関 係はいくつかの属性で特徴的な傾向を読み取ることができた。たと えば, 単身者は, 建物の倒壊や避難場所を知らないといった不備を 感じながら，特に対策をとっていない。

都市生活者として抽出した東京の木造住宅密集地域居住者, それ

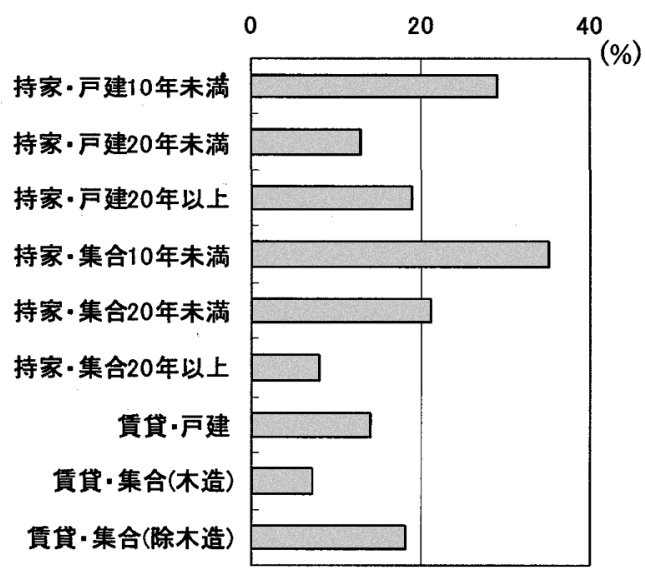

図4「背の高い家具を置かない」回答と住宅タイプの関係

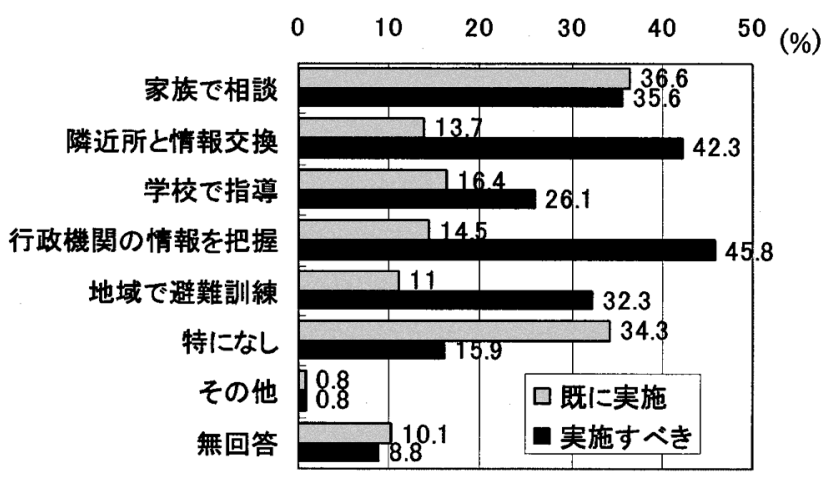

図 5 災害に対する情報コミュニケーション

以外の東京 23 区居住者と，それ以外の地域の居住者との間に特徴 的な差悓られなかったことから，居住者のリスク感覚は，居住地 域の特性によらないことが窥える。また，住宅内の不備と周辺地域 の不備の連続性については, 本調査の範囲で有効な結果を示すこと はできなかった。

災害に対する情報コミュニケーションについては，行政機関の情 報把握，近隣との情報交換なども含め，実施すべきだと思いながら 多くは未だ実施されていない。

今後は, リスク要因毎の問題点を詳細に分析し, 生活リスクの改 善に向けて取り組んでいきたいと考えている。

\section{参考文献}

1）青木仁, 中山和美：生活環境の安全性向上方策の最適化のための検討の 提案 ゼロ・リスク・エンバイロメントの構築を目指して(その 2), 日 本建築学会学術講演梗概集 F·1 $1, p p .875 \cdot 876 ， 2005$

2）中山和美, 青木仁: 住生活における防災・防犯に対する意識調査 ゼロ・ リスク・エンバイロメントの構築を目指して(その 2), 日本建築学会学 很講演梗概集 F·1, pp.877·878, 2005

3）齋藤正俊，熊谷良雄，系井川栄一：簡易的火災延焼リスク算定のための 基本モデルの構築と市街地集計データを用いたリスク概算の試み一木 造密集市街地における火炎延焼リスクの簡易的評価手法に関する研究 (その 1 ) 一, 日本建筑学会計画系論文集 NO.604, pp.115·122, 2006.6

4） 今泉恭一, 浅見泰司: 震災時の道路閉塞推定に関する研究一防災街づく りのための密集住宅市街地整備方策の定量的比較分析一, 日本建築学会 計画系論文集 NO.529, pp.225-237, 2000.3

5）古川容子, 村井裕㭷, 長谷見雄二, 野村 歡, 八藤後 猛, 志田弘二： 共同住宅における高齢者の避難計画に関する研究 シルバーピアにお ける防火・避難対策実態調査結果から，日本建築学会計画系論文集 NO.555, pp.1·7, 2002.5

6）国土交通省：平成 15 年住宅需要実熊調査結果

[2006年10月20日原稿受理２007年 2 月19日採用決定］ 